\title{
Corresponding Makeup of the Art Market of Erie, Pennsylvania with Regional Success
}

\author{
Cassandra Askins ${ }^{1}$, Robert Hodgson ${ }^{1 \#}$ and Jeffrey Taylor ${ }^{1 \#}$ \\ ${ }^{1}$ McDowell High School, Erie, PA, USA \\ \#Advisor
}

ABSTRACT

The art market is a sector of the economy that holds great significance in terms of composition and economic impact. Information pertaining to the for profits of the market is often difficult to obtain, leading to a lack of research in the field. A Colorado based report explored the for-profit arts of the state using EMSI data to overcome for profits lack of transparency. This report presented the art market of Colorado as having a major economic impact and served as a foundation for further case studies of the art economy within the nation. Additionally, though diversity in markets generally corresponds with economic success, the racial demographics within the art market as a whole show the market to be predominantly white. This paper consists of four sections specialized to answer the question, "To what extent does the makeup of the art economy of Erie, Pennsylvania correspond with regional success?". First, I review the current literature regarding arts and their relationship with economics. The second section is developing a multipronged replicable methodology geared towards city level analysis that corresponds the makeup of a market to its economic impact. The third section analyzes the findings the methodology provides, and the final section explores the implications this study has in regard to the city investigated and others in the field of art economics moving forward.

\section{Introduction}

From simple side-walk chalk in the driveway, to massive murals engulfing the walls of a building, art is a part of everyone's life. Art is defined as the expression or application of human creative skill and imagination (Oxford). By definition, this form of sensory expression is ubiquitous to the human experience. However, knowledge regarding the economic processes necessary for the universalized appreciation of the arts is not as well known. There is an entire economy revolving around the art industry that is often unacknowledged and left purposefully opaque due t2019o lack of disclosure by primary actors.

A market is a composition of systems, institutions, procedures, social relations or infrastructures whereby parties engage in exchange (Taylor, 2019). The art market, in turn, is the marketplace of producers and consumers trading in commodities, services, and works of art. This market can be broken down multiple ways; it consists of primary ${ }^{1}$ and secondary ${ }^{2}$ sectors alongside for profit and nonprofit organizations that all play a factor in the market's economic impact. Actors falling under the for-profit sector of this economy are especially problematic in the retrieval of reliable economic data (McAndrew, 2018).

\footnotetext{
${ }^{1}$ Art galleries and artists who sell their artwork directly.

${ }^{2}$ Sale of art from the primary market for the second (or more) time.
} 
While analysis concerning the art market has occurred in regards to market composition and economic impact, few have analyzed their combined effects on a regional level. Prevalence of this gap in research is most plausibly attributed to the lack of transparency within the economics of the art economy (Taylor, 2019).

\section{Literature Review}

\section{A: Market Composition}

Before discussing the inner workings of the actors that facilitate the art market's function, a definition of an art market is deemed necessary. A market or marketplace is a type of mechanism that functions to facilitate exchange, synergism, and distribution of goods and services between buyers, sellers, and any intermediaries (Al-Attili, 2005, My Accounting Course). Though researchers interpret and define the art market in diverse ways dependent on what they wish to indigate, the economy is established as a marketplace where ownership and exchange of commodities, services, works of art, and design products are situated (Taylor, 2019).

There are two primary sections that overlap and make up the art market: primary and secondary actors, and for profit and nonprofit actors. Primary markets, otherwise known as contemporary art markets, are markets that interact with the buyers and producers. It consists primarily of art galleries and artists who sell artwork directly (Santagata, 1995). Individuals involved within this market end up determining the position of the market of the artist's work, therefore impacting future prices (Taylor, 2019). Secondary art markets, as the name entails, refer to the sale of art for the second time. The determinants of supply and demand are already established within the secondary market. Art sold within this market is usually facilitated through auction houses, where public sales occur (Alrights.me).

The nonprofit sector of the arts can be studied fairly easily because US organizations are required to report their income publicly (International Revenue Service). US501(c)3 requires this disclosure of income; however, disclosure is usually beneficial as it boosts the confidence and hence contribution from nonprofit donors (McAndrew, 2018). For profit art, by contrast, prioritizes privileged information, such as that of income, which signifies opacity in economic data available. For profit organizations within the arts consist of artists and galleries, which are often run by self-employed individuals (McAndrew, 2018).

At the foundation of these markets are the individual occupations. The distribution across occupations within the art market, otherwise known as the market's occupational structure, signals the market's level of diversification (Dictionary of Sociology). Diversification indicates development alongside market volatility. A high level of diversification, or relatively equal distribution of individuals among available market job openings, helps manage volatility and provide a more stable path for equitable growth and development (Saleth, 1997).

Composition of the art market also consists of demographics. Prior research has indicated a systematic exclusion of racial minorities within the arts. In the United States, the population of people engaged with the arts is proportionally more white than the U.S. population in whole as reported by the SPPA ${ }^{3}$ (Rosenstein, 2005). Further research has suggested that the art economy is highly profitable at the expense of inequality. Social structure is prudent in the arts because elites within the market need to maintain and define class boundaries to participate in the arts resulting in a correspondence of class inequality. The demand for arts and cultural products is positively related to high economic diversity but negatively related to educational and occupational diversity (Americans for the Arts, 2019). Racial diversity, however, is beneficial in the economy because it positively impacts business ventures and reinforces the notion of equality of opportunity (Herring, 2017).

\footnotetext{
${ }^{3}$ Survey of Public Participation in the Arts
} 


\section{B: Market Impact}

Impact within the art economy can be measured monetarily and occupationally. The measure of gross domestic product (GDP) looks towards market output in respect to currency. A higher GDP indicates more valuable goods and services have been created and a higher mean income of the region to purchase said goods (Fernando, 2021). The quantity of individuals in the workforce is utilized to measure occupations within a region. More jobs equate to a stimulation in economic growth and decrease in unemployment (Levine, 2013).

The actors that comprise the art economy play a significant role in the economy of the world. A global report by Ernst \& Young indicates that the cultural and creative economy contributes 30 million jobs and $\$ 2.25$ trillion annually (Zarobell, 2017). In 2019, this market's economic activity in the United States accounted for 4.3 percent, or $\$ 919.7$ billion, of GDP (BEA, 2021). The nonprofit arts industry of the U.S. generates \$135 billion in economic activity annually, supporting 4.1 million jobs and generating 22.3 billion in revenue (Americans for the Arts, 2019). This leaves billions of dollars in revenue and countless jobs unaccounted for within the for-profit arts in the United States.

\section{C: Regional Analysis}

The investment bank UBS and the Art Basel art fair have released a report for the last two years on the global art market, but it is based on voluntary surveys, which have limitations in regards to biases and sample size (McAndrew, 2018). In an Americans for the Arts study, the nonprofit and cultural industries of the United States art market was investigated. This study found that these industries alone had a major positive impact on the economy of the United States. Within this study, project economists from the Georgia Institute of Technology customized input-output analysis models ${ }^{4}$ for each study region in order to provide valuable economic impact data about the nonprofit arts and culture industries. Input-output analysis was utilized to calculate economic prosperity (Americans for the Arts, 2019). This report, however, did not take into account the for-profit arts.

Disclosure of economic data in respect to for profit arts is more difficult to obtain access to, hence the reason as to why fewer reports have been conducted exploring their impact (Taylor, 2019). These contrasting dealings of artists and art-based businesses conducting their own sales remained essentially unmeasured until Dr. Jeffery Taylor published a report regarding the commercial arts within the state of Colorado. This report looked towards the industrial and occupational actors of the Colorado art market, utilizing economic data from Creative Vitality Suite (CV Suite), a data service made available by the Western Arts Federation (WESTAF). This granted access to for profit economic arts data left previously obscured. A cross annual analysis of the art market of Colorado showed significant growth of the market occupationally and monetarily over the years of 2017-2018. The findings were used to connect the arts to entrepreneurship and regional economic success (Taylor, 2019).

\section{D: Gap}

While state level analysis of the art market has been conducted in Colorado, the for-profit arts remain widely unexplored in regards to eastern States within the US and cities as a whole (Taylor, 2019). Reports on a city scale focused on large metropolitan areas such as that of New York City (McAndrew, 2020). This leaves a gap to investigate smaller cities' for-profit art economies. Furthermore, composition of the arts' actors have yet to be studied regionally in relation to the economy's success. The lack of regional analysis of art markets alongside their seemingly vast economic impact led me to my gap: a case-study of a post-industrial city's art economy with the aim to find possible root causes, through the investigation of market composition, that communicate the success of the art market in a region.

\footnotetext{
${ }^{4} \mathrm{~A}$ large-scale economic analysis based on the relationships between different sectors or industries in an economy.
} 


\section{Methodology}

The methodology of this paper is split into four sections: 1. justifying the location of study, 2. warranting the source of the data, 3. determining what constitutes the makeup of the art economy, 4. measuring the regional success within the case study boundaries. This methodology is designed towards answering the research question, "To what extent does the makeup of the art economy of Erie, Pennsylvania correspond with regional success?".

\section{A: Location}

Erie, Pennsylvania was chosen for this research due to the city's lack of in-depth art market analysis. Furthermore, Erie holds characteristics that are not represented within other reports; these characteristics include it not being the largest metropolitan area within the state, having a significantly higher poverty rate than the national average, and being situated on the rust belt ${ }^{5}$. As a result, Erie's manufacturing sector still continues to remain prominent in the general local economy, with emerging economic drivers in other sectors (Sutton, 2016). The Erie Art Museum is the city's main art gallery and plays a significant role in revitalizing the city's infrastructure and community spaces (Erie Art Museum). I aimed to investigate the composition and impact of the arts to aid in facilitating necessary community change in Erie, Pennsylvania.

\section{B: Data Sources}

Due to the lack of availability of for-profit economic information pertaining to the art market, the online tool of CV Suite was utilized. I obtained all Erie MSA art market specific occupational, demographic, and economic data from the CV Suite organization. Specifically, I made use of CV Suite's Erie, Pennsylvania snapshot report, Pennsylvania snapshot report, Erie, Pennsylvania CVI breakdown, and Erie, Pennsylvania creative occupational report. All data obtained was from 2018-2019, the most recent, complete years in which information was available. CV Suite makes use of EMSI (Economic Modeling Specialists International) data, which utilizes labor statistics, tax data, and other economic data organized by occupation and industry. It takes the strengths of one source to make up for the weaknesses of another. This provides a complete and comprehensive dataset in regards to the for profit arts, a section of the art economy left previously obscured. This was the same data employed by Dr. Jeffrey Taylor in regards to evaluating the for profits of the art market of Colorado. Because the CV Suite tool also provides comprehensive breakdowns on smaller jurisdictions, an evaluation of the Erie metropolitan statistical area (MSA) was made possible with equal comprehension.

\section{C: Occupations}

In accordance with prior reports utilizing the CV Suite tool, I aimed to select occupations within the art economy that would correspond with the goal of my study. These occupations consisted of the for-profit visual arts Standard Occupational Codes (SOC) justified by the Colorado report with the addition of jobs pertaining to cultural aspects of a region based jobs merely to have a broader understanding of the Erie Art Market's occupational structure (Taylor, 2019). Loosely, inclusion of these occupational codes were based on the definition of creating visual arts pertaining to either the primary or secondary sector. After selection, cross comparison of population distribution will be analyzed to see the diversification of the occupational structure within the arts of Erie, PA, as diversification is a large indicator

\footnotetext{
${ }^{5}$ A section of the northeastern U.S. where industries and factories, previously rampant, have decreased in importance.
} 
of development, market volatility, and equity in growth (Saleth, 1997). The appendix includes the SOC codes selected alongside justification for their inclusion.

\section{D: Demographics}

Furthermore, the makeup of the art economy consists of demographic distribution. Though the term demographics is broad in definition, I will be focusing on racial distribution within the art economy of Erie, Pennsylvania. This is partially due to the drastic difference in racial makeup from the inner-city area compared to the suburban outreaches alongside research indicating a lack of racial diversity present in the art market (Data USA, Rosenstein 2005). This indicates that racial distribution of the art economy would hold broader implications towards the availability of the market for all citizens of Erie. Prior studies regarding the art economy utilized gender, ethnicity, race, and veteran status demographics to find shared characteristics in the market (White, 2017). The purpose of finding shared characteristics will be the goal for this paper; however, like prior methodologies those similarities cannot be groundless. Thus, I will be finding the racial demographic distribution of Erie and comparing that to the distribution within the art market of Erie (Rosenstein 2005). I will be utilizing demographic data provided by CV Suite in relation to the art market of Erie and city-data demographic information in relation to Erie (www.city-data.com).

\section{E: Proportional Comparison}

The measurement of Erie in comparison to Pennsylvania is to be analyzed two-fold in order to determine whether or not the city is positively or negatively contributing to the state economy.

First, I chose to integrate a methodology of comparison in order to see the occupational contribution of Erie compared to that of Pennsylvania. My prior methodology, mentioned in section C, inspected the distribution of the occupations within Erie. With this, I aimed to answer my research question by uncovering the occupational impact the art market of Erie had. I utilized CV Suite's arts occupational data in respect to Erie and Pennsylvania in order to find the number of art occupations on the city level and the state level. I found the percent of Erie art occupations comparative to Pennsylvania art occupations. Next, I compared the population of Erie in respect to Pennsylvania using Census data to get an outline of the city's relative proportion. I then found the proportions of the occupations within Erie in respect to Pennsylvania. I finalized by using the percent difference formula (shown in figure 1.2) in regards to the proportions gathered to find any significant differences. A difference of $5 \%$ or greater would indicate significance in difference, and a difference of $5 \%$ or less would indicate no significance in difference. Although this formula is usually used to compare change in one measurable quantity over a change in time, it can be used to find the difference in these proportions due to their shared metric. This application of difference is justified through similar data analysis from CV Suite in regards to the measure of CVI. As a baseline, we would expect the occupational proportion to be similar to the population proportion. However, due to Erie's comparatively high poverty rate, the occupational proportion is expected to be lower than the population proportion (Census, 2020). Modeled off data analysis from CV Suite, if the art market occupational proportion is greater than the overall occupational proportion, then Erie is positively contributing to the state's art economy. If the art market occupational proportion is lower than the overall occupational proportion, then Erie is negatively contributing to the state's art economy. If all the proportions are similar, then Erie is in line with the State. 


\section{PERCENT DIFFERENCE FORMULA}

$$
p=\frac{|a-b|}{(a+b) \div 2} \times 100
$$

Figure 1.1. Percent Difference Formula

Second, inclusion of a creative vitality index (CVI), an index provided by CV Suite, was integrated in the methodology. The CVI value is composed of $40 \%$ creative occupations, $40 \%$ industry sales, and $20 \%$ nonprofit revenues, meaning it takes into account multiple facets of the art market's impacts. "1" is given as a baseline to the state or country in which a region is being compared to. An index value greater than "1" indicates that a region has a higher level of creative activity than the state or national average in which it is compared to, thus positively contributing to the state or nation. With an index value below "1", the inverse is also true.

\section{Data Analysis}

\section{A. Occupations}

The occupational structure of the art market of Erie, Pennsylvania consists of a total of 1,472 jobs in 2019 with a net $0 \%$ gain from 2018. Photographers take up 473 of those occupations, followed by graphic designers with less than half of that at 205 jobs. Fine artists, including painters, sculptors, and illustrators come in third at 156 occupations and art directors follow with 120 occupations. The rest of the occupational codes selected ranged from 1-63 in job(s). Figure 2.1 shows the distribution of occupations selected from 2018-2019. Due to the high concentration of occupations in photography and low concentrations of occupations in the majority of the rest of the fields selected, the occupational structure of this market is not diverse.

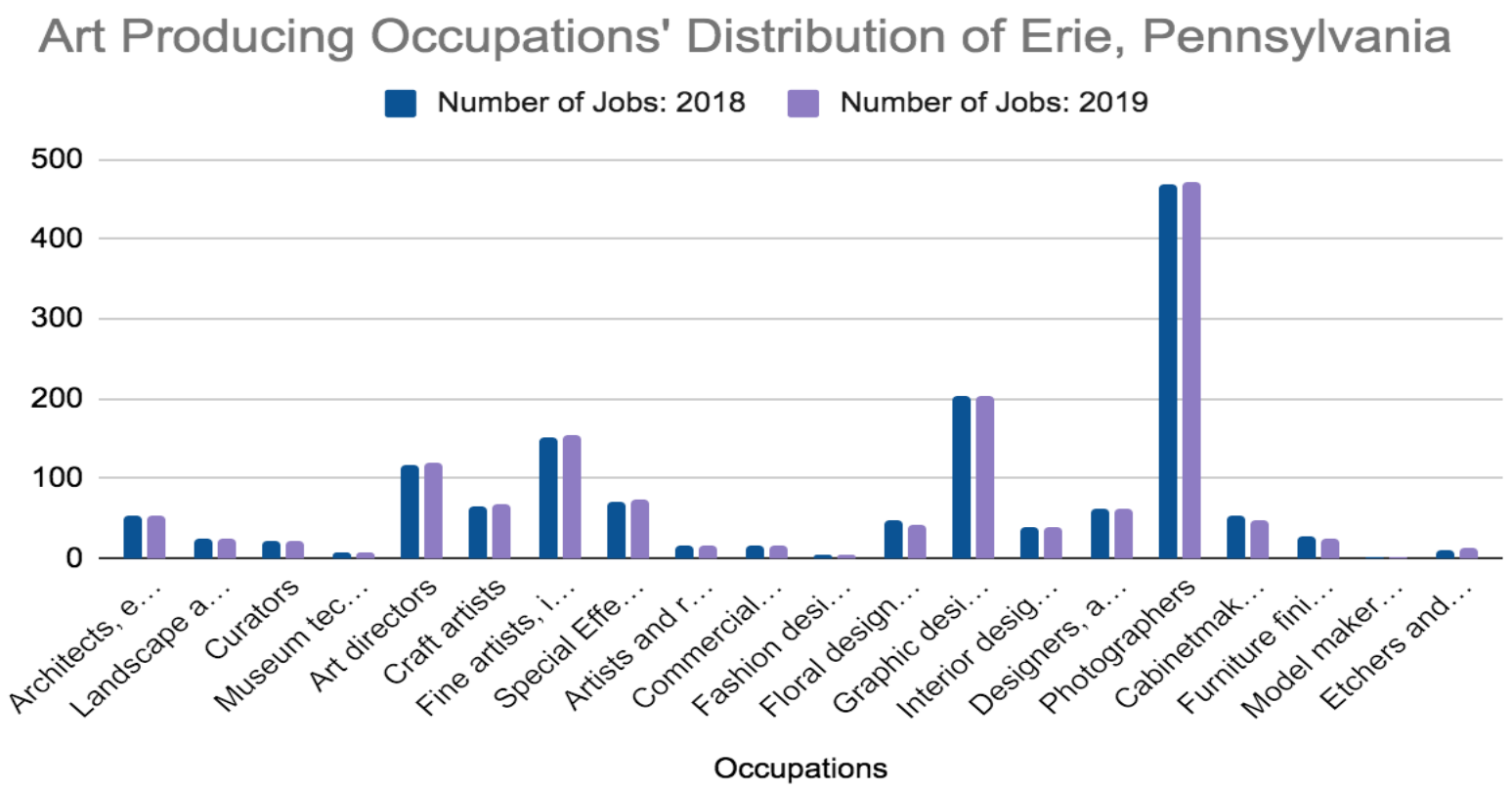

Figure 2.1. Art Producing Occupations' Distribution of Erie, Pennsylvania 


\section{B: Demographics}

In both the racial demographic distribution for Erie alongside its art market, the white population makes up the majority. When comparing figures 3.1 and 3.2, the white population of the art market of Erie is significantly greater than the white population of Erie as a whole. This entails lower racial minority participation in the arts as compared to city population proportion.

Races of Erie, PA Art Market (2019)

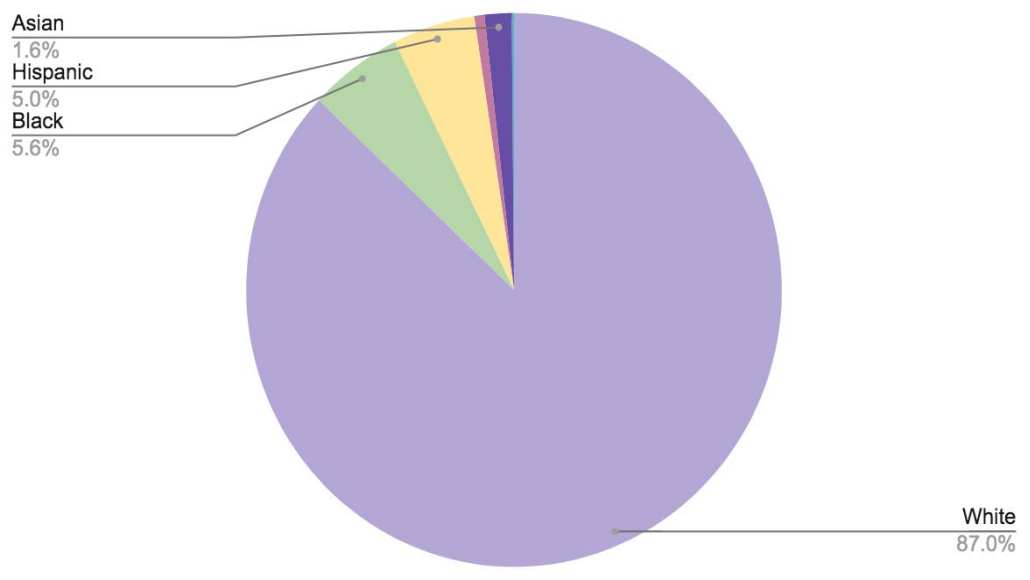

\begin{tabular}{|c|c|}
\hline White & $87.0 \%$ \\
\hline Black & $5.6 \%$ \\
\hline Hispanic & $5.0 \%$ \\
\hline$\square$ Two or More Race & $0.6 \%$ \\
\hline Asian & $1.6 \%$ \\
\hline American Indian & $0.1 \%$ \\
\hline Other & $0.0 \%$ \\
\hline
\end{tabular}

Figure 3.1. Races of Erie, PA Art Market (2019)

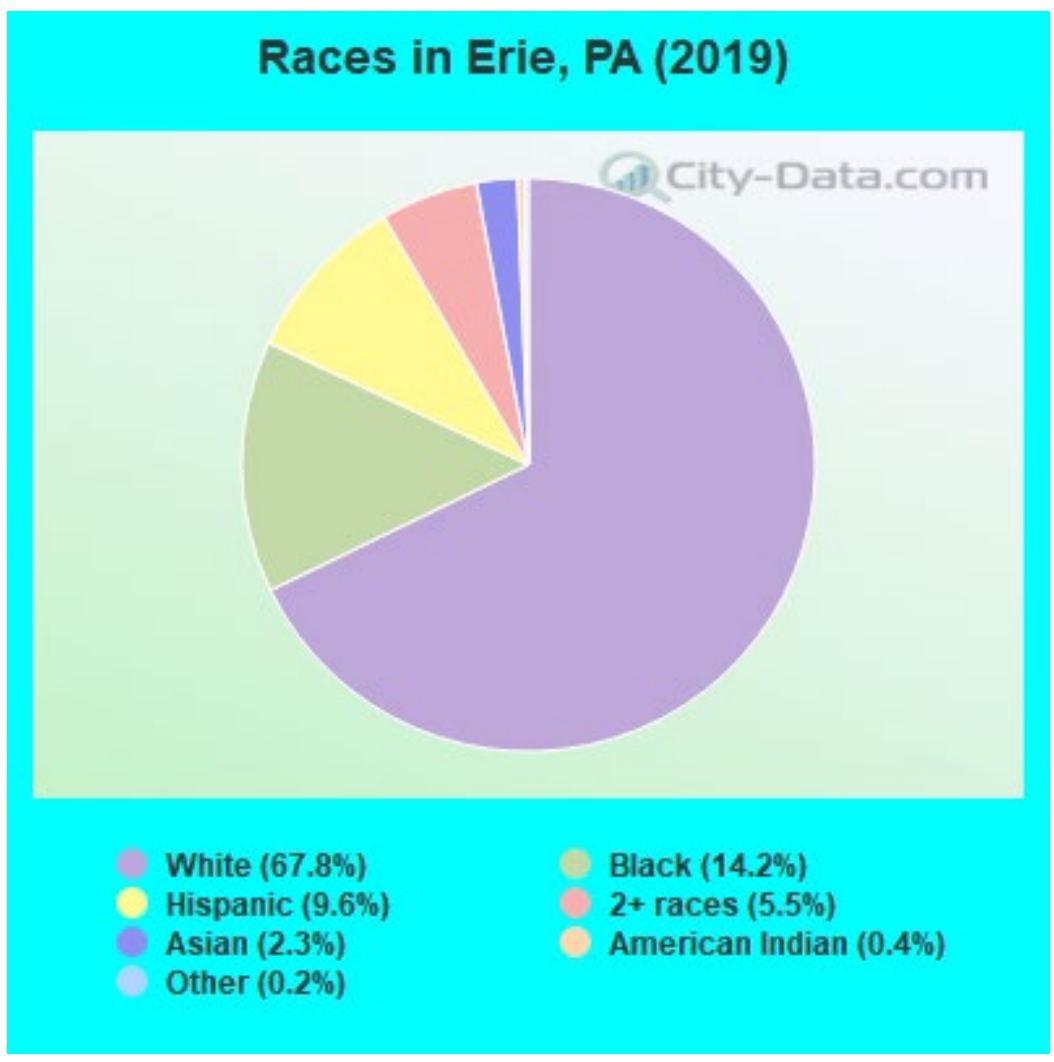

Figure 3.2. Races in Erie, PA (2010). Source: city-data.com 


\section{C: Proportional Comparison}

As depicted in figure 4.1, the population of Erie makes up 2.14\% of the population of Pennsylvania, the occupations of Erie make up $1.96 \%$ of the occupations of Pennsylvania, and the art occupations of Erie make up $0.79 \%$ of the art occupations of Pennsylvania. When we plug those proportions into the percent difference formula, there is an $8.4 \%$ difference in Erie's proportion of occupations compared to the population proportion. There is a $60.0 \%$ difference in Erie's proportion of creative occupations compared to the general occupation proportion, and there is a $63.1 \%$ difference in Erie's proportion of creative occupations compared to the population proportion. Although there is a fair difference between occupational proportion and population proportion, that can be attributed to the above average unemployment rate of Erie compared to Pennsylvania. This entails that Erie is negatively contributing to the overall occupation of the state. The drastic difference in proportion of art occupations, in comparison to overall occupations, indicates that the art market of Erie holds a significant negative impact on the occupations of the art market of the state.

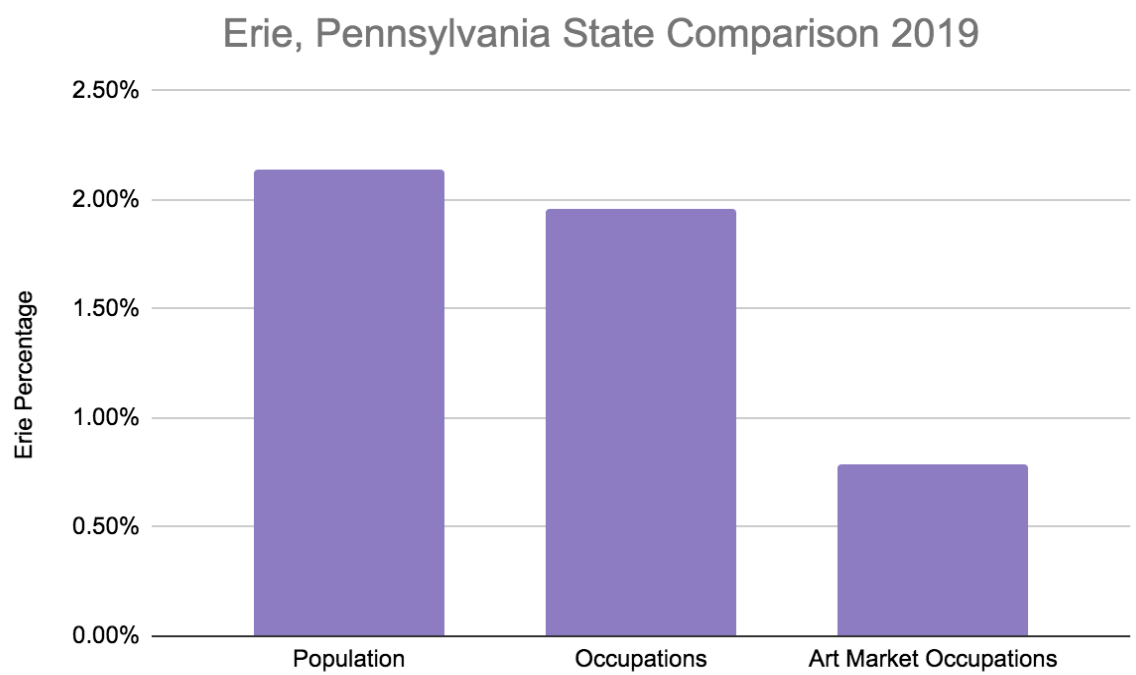

Figure 4.1 Erie, Pennsylvania State Comparison 2019

In terms of the Creative Vitality Index, most recent data from 2019 showed Erie with a CVI value of 0.76 in comparison to Pennsylvania (Figure 4.2) and a CVI value of 0.64 in comparison to the United States (Figure 4.3). There is a general trend of increase in CVI value from 2016-2019 evident in Erie in relation to the state alongside the country. CVI is compared to the baseline of 1 , which is given to the chosen state or country the city is located. The CVI of Erie in comparison to Pennsylvania is greater than the CVI of Erie in comparison to the United States. This indicates Pennsylvania having a less prosperous relative creative economy as compared to the U.S.. Because all of the CVI values of Erie are below 1, Erie's creative economy is both negatively contributing to the creative economy of the state alongside the creative economy of the country. 


\section{Past Performance of Erie, PA CVI Compared to Pennsylvania} 0.8

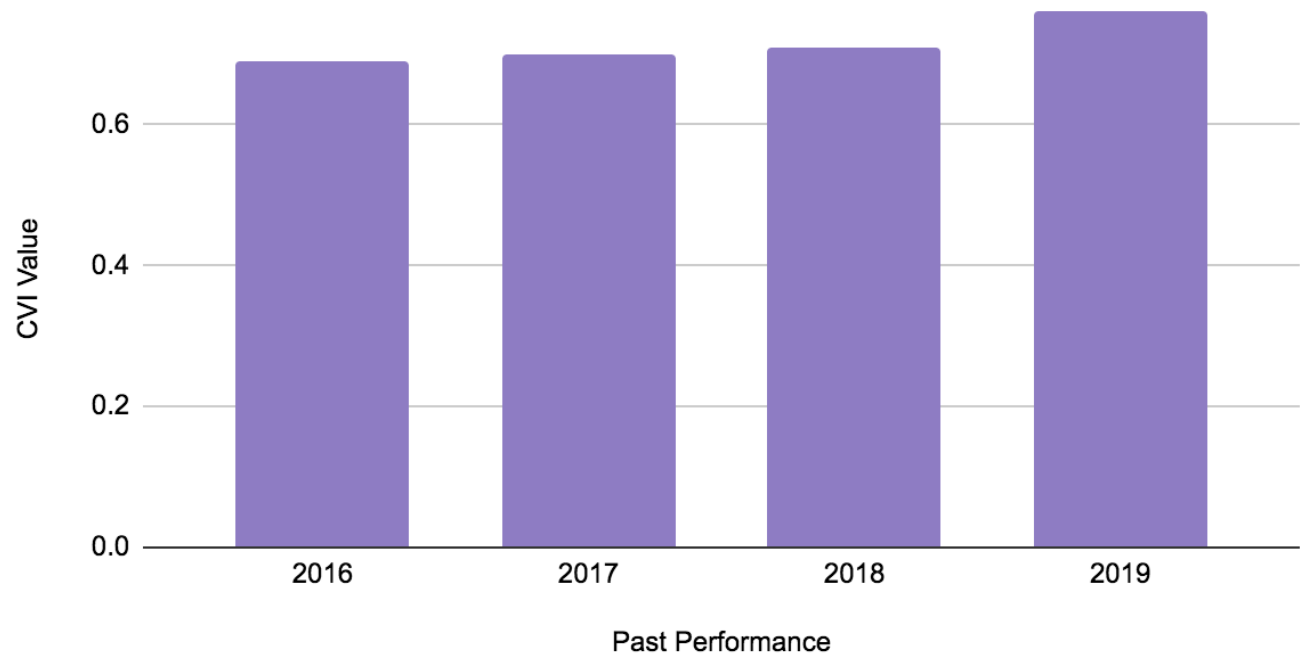

Figure 4.2 Past Performance of Erie, PA CVI Compared to Pennsylvania

\section{Past Performance of Erie, PA CVI Compared to the USA}

0.8

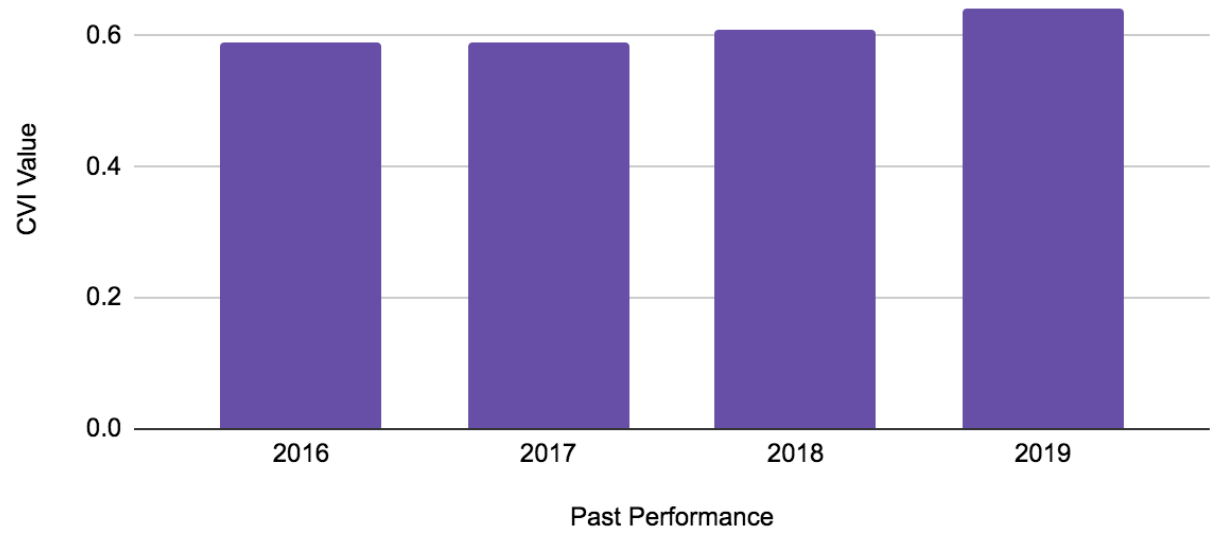

Figure 4.3 Past performance of Erie, PA CVI Compared to the USA 


\section{Conclusion}

Circling back to my research question, "To what extent does the makeup of the art economy of Erie, Pennsylvania correspond with regional success?", it is evident that a lack of diversification occupationally and demographically are presented in accordance with negative proportional contribution to state occupations and negative proportional contribution to creative vitality on both a state and national basis. This indicates that the high occupational skew evaluated is associated with lower occupational employment in the art market of Erie, Pennsylvania.

\section{A. Implications}

The scope of my research includes implications of applying the results discovered towards future policy action within Erie, Pennsylvania.

\section{Occupations}

The high skew towards photographers in occupational structure indicates a lower degree of diversification and hence development within the art economy of Erie. Due to the proven benefits of a heterogeneous economy, policies could be implemented within Erie to foster a wider participation occupationally in the arts. Because the art market is a huge determinate of entrepreneurship, and entrepreneurship positively correlates with regional economic success, policy implementation to destratify the occupational structure of the art market would be beneficial to the region. Inversely, the lack of diversification could be actively contributing to inequality within the area (Gori and Sakamoto, 2015). This policy could range from funding certain art industries to increasing community art events with the goal of spreading awareness.

\section{Demographics}

This research would support advocacy of programs that foster minority inclusion within the art economy of Erie, Pennsylvania. My data supports that of prior research by showing a lower level of racial minority participation in the arts (Rosenstein, 2005). Due to the denser population of racial minorities focused in the inner city area of Erie, it is possible that those living in the city are not provided equal access to employment in the art market (Census, 2020). Consequently, the inner city consisting of lower income households supports prior research indicating the art economy is mainly available to those from higher socioeconomic locations, advancing wealth inequality (Americans for the Arts, 2019). Further research could investigate what specific barriers are posed by the region to limit racial minority involvement. The lack of diversity in the art market could also be an indicator of a weaker economy due to the fact that a diverse workforce can appeal to a larger share of the consumer market (Herring, 2017). Broader appeal would result in furthered participation and hence greater economic growth of the market. Passing policies that support art programs with the intent to continue education in the arts, support community-based ethnic arts organizations, and advocate for availability of spaces to practice said programs, are steps to equitable participation among racial minorities in the art market (Rosenstein, 2005).

\section{Proportional Comparison}

Because I discovered that Erie is negatively contributing towards the art economy of Pennsylvania in terms of both market employment and CVI, policymakers of the region could utilize this information to focus efforts on boosting the city's art market. That focus could be centralized toward occupational employment in the area. 


\section{B. Limitations}

With respect to the data obtained, there were limitations that have to be considered when evaluating the results generated. First of all, due to financial constraints regarding the research process, full access to the tool of CV Suite was not possible. This was not detrimental to my research process, however, because the methodology I implemented only necessitated the use of occupational codes and snapshot reports available to me. I wasn't able to replicate prior methodology on a city level, so I ended up constructing my own based on what I aimed to study. Secondly, Erie, Pennsylvania is the only scope to which the results of my research are applicable and can be utilized to aid community going forward. This means that my results, while being an example of a rust belt city's art economy, are not universalizable to all cities with shared characteristics. Third, the most recent data available from CV Suite at the time of my research spanned from the years 2018-2019, meaning I was not able to observe the impact of the Covid-19 Pandemic. While more recent data is generally preferred, this did not hinder my project as I aimed to study the art market of Erie independently.

\section{Future Research}

My analysis on the art market focused on the general workings of the art market within a case study such as that of Erie, PA. Future researchers could explore the reasons that specific fields of art perform better than others in a certain region or just hone in on one actor or group of actors within the market and analyze their impacts. Studies could further compensate for the limitations faced within my research. This could include exploring the impact the Covid-19 pandemic had on art markets, utilizing the full CV Suite tool to provide comprehensive analysis on the arts of a region, or replicating my methodologies in other cities. Replication of city-level art market analysis could be employed to find shared characteristics in the markets of cities along the rust belt with the goal of finding market impacts.

\section{Acknowledgements}

I would like to thank Kelly Ernst from CV Suites for her help in getting me the information that I needed. Along with this I wish to thank the tool of CV Suites. I would also like to thank Dr. Jeffrey Taylor for his guidance and willingness to answer questions that I had along the research process. Finally, I would like to thank Mr Hodgson and The Education Center for the Millcreek Township School District for aiding me along the research process supportively and financially.

\section{References}

Al-Attili, Aghlab. "Unit 1 Small Agribusinesses and Markets." 1.1 What Is a Market?, 2005, www.soas.ac.uk/cedep-demos/000_P538_MSA_K3736-Demo/unit1/page_06.htm.

"Demographic." Demographic Noun, Oxford Advanced Learner's Dictionary, www.oxfordlearnersdictionaries.com/us/definition/english/demographic_1\#: :text=\%E2\%80\%8 B, and\%20different $\% 20$ groups $\% 20$ within $\% 20$ it.

"Erie City, Pennsylvania." QuickFacts, United States Census Bureau, 2020, www.census.gov/quickfacts/eriecitypennsylvania.

"Erie, PA." Data USA, datausa.io/profile/geo/erie-pa/.

"Erie, Pennsylvania." Erie, Pennsylvania (PA) Profile: Population, Maps, Real Estate, Averages, Homes, Statistics, Relocation, Travel, Jobs, Hospitals, Schools, Crime, Moving, Houses, News, Sex Offenders, www.city-data.com/city/Erie-Pennsylvania.html. 
"Exemption Requirements - 501(c)(3) Organizations." Internal Revenue Service, www.irs.gov/charities-non-profits/charitable-organizations/exemption-requirements-501c3-organ izations.

Fernando, Jason. “Gross Domestic Product (GDP).” Investopedia, Investopedia, 26 Apr. 2021, www.investopedia.com/terms/g/gdp.asp

Herring, Cedric. "Is Diversity Still a Good Thing?” American Sociological Review, vol. 82, no. 4, 2017, pp. 868-877. JSTOR, www.jstor.org/stable/26426360. Accessed 20 May 2021.

"Homepage." The Erie Art Museum, 5 May 2021, erieartmuseum.org/.

Levine, Linda. "Economic Growth and the Unemployment Rate." Congressional Research Service, 7 Jan. 2013.

Maia, Alexandre Gori, and Arthur Sakamoto. "Occupational Structure and Socioeconomic Inequality: a Comparative Study between Brazil and the United States." Economia e Sociedade, vol. 24, no. 2, 2015, pp. 229-261., doi:10.1590/1982-3533.2015v24n2art1.

McAndrew, Clare. "The NYC Art Market Report.” Independent, 19 Nov. 2020, nyartmarket.independenthq.com/.

McAndrew, Claire. The Art Market . Art Basel and USB, 2018.

"News Release." Arts and Cultural Production Satellite Account, U.S. and States | U.S. Bureau of Economic Analysis (BEA), 30 Mar. 2021, 10:00 AM, www.bea.gov/news/2021/arts-and-cultural-production-satellite-account-us-and-states.

"occupational structure ." A Dictionary of Sociology. . Encyclopedia.com. 15 Apr. 2021 $<$ https://www.encyclopedia.com>.

Rosenstein, Carole. "Diversity and Participation in the Arts Insights from the Bay Area." The Urban Institute, Oct. 2005, pp. 1-4.

Saleth, R. Maria. “Occupational Diversification among Rural Groups: A Case Study of Rural Transformation in Tamil Nadu." Economic and Political Weekly, vol. 32, no. 30, 1997, pp. 1908-1917. JSTOR, www.jstor.org/stable/4405683. Accessed 19 May 2021.

Santagata, Walter. "Institutional Anomalies in the Contemporary Art Market." Journal of Cultural Economics, vol. 19, no. 2, 1995, pp. 187-197. JSTOR, www.jstor.org/stable/41810546. Accessed 19 May 2021.

"Statement on Arts, Jobs, and the Economy." Americans for the Arts, 15 May 2019, www.americansforthearts.org/news-room/arts-mobilization-center/statement-on-arts-jobs-and-theeconomy.

Sutton, Rebecca. "Manufacturing the Arts in Erie.” NEA, 22 Aug. 2016, Www.arts.gov/art-works/2016/manufacturing-arts-erie.

Taylor, Jeffrey, et al. "Measuring Art Markets: The Colorado Art Market in 2017." Artivate, vol. 8, no. 2, 2019, pp. 5-19. JSTOR, www.jstor.org/stable/10.34053/artivate.8.2.1. Accessed 18 May 2021.

"What Are Intermediaries? - Definition: Meaning: Example." My Accounting Course, www.myaccountingcourse.com/accounting-dictionary/intermediaries.

White, Jason C. "Analyzing Entrepreneurship in the U.S. Arts Sector: Identifying Arts Entrepreneurs' Demographics and Shared Characteristics." Artivate, vol. 6, no. 1, 2017 , pp. 8-32. JSTOR, www.jstor.org/stable/10.34053/artivate.6.1.008. Accessed 20 May 2021.

Zarobell, John. "Art and the Global Economy." University of California Press, 2017, doi:10.1525/9780520965270. 


\section{Appendix: Data Sources}

1. City-Data.com

a. Racial demographic data

2. Economic Modeling Specialists International (EMSI)

a. Racial demographic data of art market

b. Occupational art market data (SOC codes)

\begin{tabular}{|c|c|c|}
\hline $\begin{array}{l}\text { SOC } \\
\text { Codes }\end{array}$ & Name of Occupation & Justification \\
\hline $17-1011$ & $\begin{array}{l}\text { Architects, except land- } \\
\text { scape }\end{array}$ & $\begin{array}{l}\text { They plan and design structures, such as private residences, office build- } \\
\text { ings, theaters, factories, and other structural property. }\end{array}$ \\
\hline $17-1012$ & Landscape architects & $\begin{array}{l}\text { They design attractive and functional public parks, gardens, playgrounds, } \\
\text { residential areas, college campuses, and public spaces. }\end{array}$ \\
\hline $25-4012$ & Curators & $\begin{array}{l}\text { Often associated with the Experiential Sector, still curators usually func- } \\
\text { tion as the driver for a museum's acquisition policy, and therefore, play a } \\
\text { key role in the art market. Curators are often also employed by commer- } \\
\text { cial galleries and therefore play a direct role in the market. }\end{array}$ \\
\hline $25-4013$ & $\begin{array}{l}\text { Museum Techni- } \\
\text { cians/Conservators }\end{array}$ & $\begin{array}{l}\text { Working in both the for profit and nonprofit sector of the art market, they } \\
\text { restore, maintain, or prepare objects in museum collections for storage, re- } \\
\text { search, or exhibit. }\end{array}$ \\
\hline $27-1011$ & Art directors & $\begin{array}{l}\text { Although usually found in the commercial art business, art directors and } \\
\text { their teams still produce an aesthetic product which is purchased by their } \\
\text { client. }\end{array}$ \\
\hline $27-1012$ & Craft artists & They produce applied art and design objects for sale. \\
\hline $27-1013$ & $\begin{array}{l}\text { Fine artists, including } \\
\text { painters, sculptors, il- } \\
\text { lustrators }\end{array}$ & These producers conform to our most traditional concepts of artists. \\
\hline $27-1014$ & $\begin{array}{l}\text { Multimedia artists and } \\
\text { animators }\end{array}$ & The artists sell a digital art product of their creation. \\
\hline $27-1019$ & $\begin{array}{l}\text { Artists and related } \\
\text { workers }\end{array}$ & $\begin{array}{l}\text { A general category with which many less traditional artists elect identify } \\
\text { themselves. }\end{array}$ \\
\hline $27-1021$ & $\begin{array}{l}\text { Commercial and indus- } \\
\text { trial designers }\end{array}$ & $\begin{array}{l}\text { They develop and design manufactured products, such as cars, home ap- } \\
\text { pliances, and children's toys. Combine artistic talent with research on } \\
\text { product use, marketing, and materials to create the most functional and } \\
\text { appealing product design. }\end{array}$ \\
\hline $27-1022$ & Fashion designers & They produce a fashion textile product that is purchased by a client. \\
\hline
\end{tabular}




\begin{tabular}{|c|c|c|}
\hline $27-1023$ & Floral designers & $\begin{array}{l}\text { They cut and arrange various kinds of flowers and greenery to make deco- } \\
\text { rative displays that are sold to companies and people. }\end{array}$ \\
\hline $27-1024$ & Graphic designers & They produce artworks for advertising and publication purposes \\
\hline $27-1025$ & Interior designers & $\begin{array}{l}\text { They function as the art agents for the furniture (both new and antique) } \\
\text { business and therefore play a merchant-like intermediary role. }\end{array}$ \\
\hline $27-1029$ & Designers, all others & $\begin{array}{l}\text { This designation serves as a general category for designers who produce a } \\
\text { variety of aesthetic assemblages that are purchased by clients. }\end{array}$ \\
\hline $27-4021$ & Photographers & $\begin{array}{l}\text { They produce photographs, either printed or digital, for clients who pur- } \\
\text { chase those images. We elected to include only still photographers, but } \\
\text { not to include makers of video and other motion-picture products. }\end{array}$ \\
\hline $51-7011$ & $\begin{array}{l}\text { Cabinetmakers and } \\
\text { bench carpenters }\end{array}$ & They produce the applied art of furniture. \\
\hline $51-7021$ & Furniture finishers & $\begin{array}{l}\text { They function as the conservators of the antique furniture market, as well } \\
\text { as often its merchants. }\end{array}$ \\
\hline $51-7031$ & Model makers, wood & $\begin{array}{l}\text { They fit, fasten, and assemble wood parts together to form patterns, mod- } \\
\text { els, or sections, using glue, nails, dowels, bolts, screws, and other fasten- } \\
\text { ers for retail sale or museum display. }\end{array}$ \\
\hline
\end{tabular}

\begin{tabular}{|l|l|l|}
\hline $51-9194$ & Etchers and engravers & $\begin{array}{l}\text { Engrave or etch metal, wood, rubber, or other materials. They make se- } \\
\text { rial -dimensional artworks. }\end{array}$ \\
\hline $51-9195$ & $\begin{array}{l}\text { Molders, shapers, and } \\
\text { casters (except metal } \\
\text { and plastic) }\end{array}$ & These producers make metal and ceramic objects for aesthetic purposes. \\
\hline
\end{tabular}

3. United States Census Bureau

a. Population data

b. Occupational data

4. Western States Arts Federation (WESTAF) data service CVSuite
a. CVI Index
b. Snapshot report of Erie
c. Snapshot report of Pennsylvania 